\title{
Ambient Temperature, Maternal Dexamethasone, and Postnatal Ontogeny of Leptin in the Neonatal Lamb
}

\author{
JAYSON BISPHAM, HELEN BUDGE, ALISON MOSTYN, JENNIFER DANDREA, \\ LYNNE CLARKE, DUANE H. KEISLER, MICHAEL E. SYMONDS, AND TERENCE STEPHENSON \\ Academic Division of Child Health, School of Human Development, University Hospital, Queen's Medical \\ Centre, Nottingham, NG7 2UH, U.K. [J.B., H.B., A.M., J.D., M.E.S., T.S.]; T.H. Huxley School, Imperial \\ College at Wye, University of London, Wye, Ashford, TH25 5AH, U.K. [L.C.]; and the Department of \\ Animal Sciences, University of Missouri, Columbia, Missouri 65211, U.S.A. [D.H.K.]
}

\begin{abstract}
The influence of route of delivery, ambient temperature, maternal dexamethasone treatment, and postnatal age on plasma concentrations of leptin or leptin mRNA abundance in perirenal adipose tissue was examined from 6-h-old lambs, born vaginally or delivered by cesarean section into warm $\left(30^{\circ} \mathrm{C}\right)$ or cool $\left(15^{\circ} \mathrm{C}\right)$ ambient temperatures, and from cesarean section-delivered lambs whose mothers had been treated with dexamethasone beginning $2 \mathrm{~d}$ before parturition. The ontogeny of leptin during the first month of postnatal life was also examined. In lambs born into a cool ambient temperature, but not in those born to dexamethasone-treated mothers, leptin mRNA abundance decreased within $6 \mathrm{~h}$ of birth. Plasma concentrations of leptin decreased during the first $6 \mathrm{~h}$ of life, an adaptation delayed by cesarean section birth. After the first day of postnatal life, both plasma concentrations of leptin and its mRNA increased to peak at $7 \mathrm{~d}$
\end{abstract}

\section{ABSTRACT}

of age and were positively correlated with each other, as well as with whole-body and perirenal adipose tissue weights. A similar relationship was not observed after $7 \mathrm{~d}$ of age, as plasma leptin declined despite an increase in adipose tissue weight. In conclusion, route of delivery, ambient temperature, or maternal dexamethasone therefore delays the rate of leptin disappearance after birth. Concomitantly, leptin abundance was only associated with body and adipose tissue weights for 1 week after birth, which may be coincident with the onset of peak lactation and the time at which nutrient supply should no longer be limiting to the neonate. (Pediatr Res 52: 85-90, 2002)

RT, reverse transcription

\section{Abbreviations}

UCP1, uncoupling protein-1
Leptin, the product of the obese $(o b)$ gene is secreted predominantly, but not exclusively, from adipose tissue $(1,2)$. In adults, leptin regulates both food intake and energy expenditure (3). Its role in the fetus and neonate, however, remains to be fully determined. Plasma concentrations of leptin have been shown in a variety of studies to increase with gestational age in conjunction with an increase in fetal adipose tissue deposition and mRNA abundance for leptin $(4,5)$. Within a few hours of birth, plasma leptin levels rapidly decline coincident with removal of the placenta $(6,7)$ and the need for the newborn to maximize food intake as it establishes independent thermoregulation. These temporal changes in leptin coincide with maturation of the hypothalamic-pituitary axis and other

Received July 19, 2001; accepted February 8, 2002.

Correspondence and reprint requests: Michael E. Symonds, Ph.D., Academic Division of Child Health, School of Human Development, University Hospital, Queen's Medical Centre, Nottingham, NG7 2UH, U.K.; e-mail: Michael.Symonds@nottingham.ac.uk

Supported by a Ministry of Agriculture Fisheries and Food Postgraduate Studentship (J.D.) and a University of Nottingham Postgraduate Research Scholarship (A.M.). changes in fetal adipose tissue, including the gradual rise in UCP1 (8).

Normal parturition at term is associated with a dramatic rise in UCP1 abundance and function (9) before down-regulation during the first days and weeks of postnatal life (10). The parallel increase in leptin (5) and UCP1 mRNA (11) with increasing gestation occurs at the same time that fetal cortisol production is rising (12). Maternal antenatal steroid treatment increases neonatal plasma leptin (13) and UCP1 function (14), but effects on leptin mRNA have not yet been determined. The newborn's ability to thermoregulate is enhanced by maternal dexamethasone administration, and the magnitude of response is influenced by delivery temperature (14). It is not known, however, whether route of delivery and ambient temperature influence leptin status in the newborn.

Plasma concentrations of leptin in umbilical cord blood were shown to be positively correlated with birth weight and s.c. fat mass in normally delivered infants (4). Premature infants, or those born with intrauterine growth restriction, have reduced plasma leptin (4), whereas infants born to mothers with gesta- 
tional diabetes have higher plasma leptin and more s.c. fat (13). A current point of debate is the extent to which fetal leptin is produced from the placenta or the fetus and, therefore, whether a change in placental size or adipose tissue abundance explains these differences (15). Infants born with intrauterine growth restriction often have small placentas, whereas infants of diabetic mothers usually have large placentas.

Plasma leptin appears to remain low after birth (16), and in rat pups, leptin treatments are known to induce weight loss and adipose tissue mobilization (17). It is possible that peripheral levels of leptin are maintained at low levels after birth to ensure that the neonate's appetite is high and adipose tissue deposition is maximized. This could contribute to the large amounts of adipose tissue deposited after birth, particularly in both infants and lambs, which act to improve insulation and provide an endogenous energy store. The present study was conducted to determine whether 1) route of delivery, ambient temperature, or maternal dexamethasone treatment influences plasma leptin or leptin mRNA abundance in adipose tissue, and 2) postnatal changes in adipose tissue deposition and leptin status are related.

Lambs have minimal adipose tissue stores ( 1 to $2 \%$ body weight) at birth located primarily in the perirenal area. Heat production from UCP1 in adipose tissue is maximally activated immediately after birth and is dependent on delivery temperature (9). During the first month of life, as UCP1 disappears, growth of perirenal adipose tissue is greater than any other tissue (10) and would, therefore, be predicted to result in elevated plasma leptin. However, the effects of delivery temperature or postnatal age on leptin mRNA abundance have not been investigated.

\section{METHODS}

\section{Animals}

Study 1: Adaptation at the time of birth. Study 1A: Effect of delivery temperature and maternal dexamethasone treatment. Eight Bluefaced-Leicester cross Swaledale ewes of recorded mating date and confirmed as bearing triplets were entered into the study. All ewes were individually housed 4 weeks before predicted lambing date and fed a daily diet of $0.4-0.6 \mathrm{~kg}$ of concentrate and $1.2 \mathrm{~kg}$ of hay sufficient to fully meet the total energy requirements for a late-gestation ewe. A summary of the experimental protocol is illustrated in Figure 1. Briefly, at $138 \mathrm{~d}$ gestation, four ewes were randomly selected and given an intramuscular injection of dexamethasone ( $8 \mathrm{mg}$ Dexadreson; National Veterinary Supplies, Stoke, U.K.). Cesarean section delivery was then performed on day 140 as described by Clarke et al. (9) while the four untreated ewes gave birth on d 146. Lambs from untreated ewes were not delivered at $140 \mathrm{~d}$ gestation, as they remain hypothermic and seldom survive beyond $2 \mathrm{~h}$ after birth if born by cesarean section (18). For each ewe, one lamb was immediately placed in a warm ambient temperature of $30^{\circ} \mathrm{C}$ and its sibling into a cool ambient temperature of $15^{\circ} \mathrm{C}$. The remaining fetus was euthanized by i.v. administration of barbiturate $(100 \mathrm{mg} / \mathrm{kg}$ pentobarbital sodium; Euthatal, National Veterinary Supplies). Perirenal adipose tissue was immediately removed, placed in liquid nitrogen, and

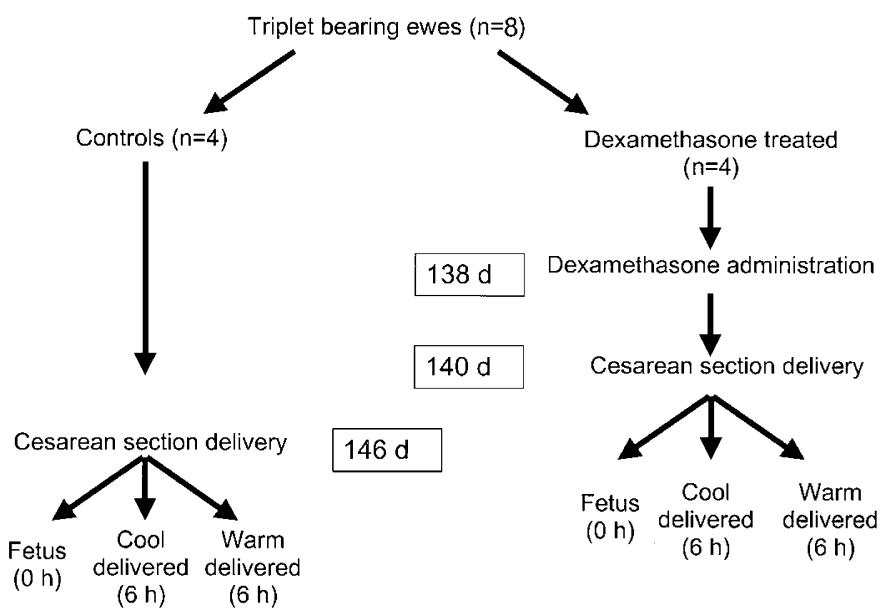

Figure 1. Summary of experimental protocol used to determine the effect of delivery temperature and maternal dexamethasone treatment on leptin mRNA abundance in adipose tissue of the neonatal lamb.

stored at $-80^{\circ} \mathrm{C}$ until analyzed. Similarly, perirenal adipose tissue was sampled from warm- and cool-delivered lambs at $6 \mathrm{~h}$ of age. All lambs remained unfed.

Study 1B: Effect of route of delivery. Twenty Bluefaced Leicester cross Swaledale ewes of recorded mating date and confirmed as bearing twins were entered into the study. All ewes were individually housed and fed as described in study 1A. Ten sets of twins were delivered by caesarean section at $146 \mathrm{~d}$ gestation into warm or cool ambient temperatures as outlined in study 1A. An umbilical cord blood sample was taken immediately before cord clamping. A jugular vein catheter was then inserted into each lamb after local anesthesia as described by Clarke et al. (9), and blood samples were taken hourly for the first $5 \mathrm{~h}$ after birth. Samples were drawn into heparinized syringes, transferred to ice-cold tubes, and centrifuged at $3000 \mathrm{rpm}$ for $15 \mathrm{~min}$, and the plasma was removed and stored at $-20^{\circ} \mathrm{C}$ until analyzed. A similar protocol was performed on the remaining lambs that were all born normally at term, with the modification that it was not possible to obtain umbilical cord samples. There was no effect of delivery temperature on plasma leptin in either cesarean section or vaginally delivered lambs, so only mean results with respect to route of delivery are shown.

Study 2: Postnatal Ontogeny. Twin lambs born normally at term to 22 Bluefaced Leicester cross Swaledale ewes and reared with their ewes were entered into the study. In 16 twins, one lamb from each ewe was randomly assigned to each sampling date, i.e. within $1 \mathrm{~h}$ of birth, or 1, 2, 4, 7, 14, 21, and $30 \mathrm{~d}$ after birth, with all ewes rearing single lambs after $4 \mathrm{~d}$. Jugular venous blood samples were taken from all lambs as described above (study 1A), and each lamb was euthanized to enable perirenal adipose tissue sampling. To further assess the effect of postnatal age, in the remaining six ewes, one lamb was sampled within $6 \mathrm{~h}$ of birth and its twin sampled at $30 \mathrm{~d}$. All operative procedures and experimental protocols had the required Home Office approval as designated by the Animals (Scientific Procedures) Act (1986). 


\section{Laboratory Analysis}

Total RNA was isolated from perirenal adipose tissue using Tri-Reagent (Sigma Chemical Co., Poole, U.K.). To maximize sensitivity, a two-tube approach to RT was adopted. The conditions used to generate first strand cDNA (RT) were $70^{\circ} \mathrm{C}$ (5 min), $4^{\circ} \mathrm{C}(5 \mathrm{~min}), 25^{\circ} \mathrm{C}(5 \mathrm{~min}), 25^{\circ} \mathrm{C}(10 \mathrm{~min}), 42^{\circ} \mathrm{C}(1 \mathrm{~h})$, $72^{\circ} \mathrm{C}(10 \mathrm{~min})$, and $4^{\circ} \mathrm{C}(5 \mathrm{~min})$. The $\mathrm{RT}$ reaction (final volume $20 \mu \mathrm{L})$ contained $5 \times$ cDNA (first strand) buffer $(250 \mathrm{mM}$ Tris- $\mathrm{HCl}, 40 \mathrm{mM} \mathrm{MgCl} 2,150 \mathrm{mM} \mathrm{KCl}, 5 \mathrm{mM}$ dithioerythritol, $\mathrm{pH}$ 8.5), $2 \mathrm{mM}$ deoxyribonucleotides, $1 \times$ hexanucleotide mix, $10 \mathrm{U}$ of RNase inhibitor, $10 \mathrm{U}$ of M-MLV reverse transcriptase, and $1 \mu \mathrm{g}$ of total RNA. All these commercially available products were purchased from Roche Diagnostics Ltd (Lewes, U.K.).

A set of cDNA primers to the ovine leptin gene was designed, 5'-CACCAAAACCCTCATCAAGACG-3' (27-58) and 5'-ACATTTCTGGAAGGCAGACTGG-3' (197-228, Genbank U84247), which generated a 192-bp intron-spanning product. Quantum RNA alternate 18S internal standards (Ambion, Abingdon, U.K.) were included in the multiple PCRs. The conditions of these were as follows: $94^{\circ} \mathrm{C}(2 \mathrm{~min})$ one cycle; $94^{\circ} \mathrm{C}(30 \mathrm{~s}), 60^{\circ} \mathrm{C}(30 \mathrm{~s}), 72^{\circ} \mathrm{C}(1 \mathrm{~min}) 30$ cycles; $72^{\circ} \mathrm{C}$ (7 min) one cycle. The PCR reaction (final volume, $20 \mu \mathrm{L}$ ) contained $10 \times$ PCR buffer $\left(100 \mathrm{mM}\right.$ Tris- $\mathrm{HCl}, 15 \mathrm{mM} \mathrm{MgCl}_{2}$, $500 \mathrm{mM} \mathrm{KCl}, \mathrm{pH} 8.3), 500 \mu \mathrm{M}$ deoxyribonucleotides, $1 \mathrm{mM}$ each leptin primer, $3.75 \mathrm{U}$ Taq polymerase. Agarose gel electrophoresis $(2.0 \%)$ and ethidium bromide staining confirmed the presence of both leptin and $18 \mathrm{~S}$ products of the expected sizes.

Plasma concentrations of cortisol were measured by ELISA as described by Clarke et al. (14). Leptin was determined using a validated double antibody RIA as described by Delavaud et al. (19). Plasma concentrations of leptin were assayed in duplicate $200-\mu \mathrm{L}$ samples using a rabbit anti-ovine leptin primary antibody, iodinated ovine leptin, and sheep anti-rabbit secondary antibody. The leptin intra- and interassay coefficients of variation were 4 and $11 \%(n=5)$, respectively.

\section{Statistical Analyses}

Data were subjected to Kolmogorov-Smirnov analysis to determine the distribution around the median. Normally distributed data were compared among groups by ANOVA, with nonparametric data compared by Mann-Whitney $U$ Test. When multiple comparisons were performed, multiple-way ANOVA or Kruskal-Wallis tests were used for nonparametric and parametric variables, respectively. Values are presented as means with SEM, and $p<0.05$ was taken to indicate a significant difference.

\section{RESULTS}

Study 1: Adaptation at the time of birth. Study 1A: Effect of delivery temperature and maternal dexamethasone treatment. Among near-term control lambs delivered by cesarean section into a cool, but not a warm, ambient temperature, abundance of leptin mRNA decreased significantly $(p<0.05)$ when compared with that observed in the fetus (Fig. $2 A$ ). In contrast, for dexamethasone-treated lambs no effect of delivery temperature on leptin mRNA was observed (Fig. 2B).

Study 1B: Effect of route of delivery. In all cesarean sectiondelivered lambs, plasma leptin decreased after birth (Fig. 3), with the result that by $2 \mathrm{~h}$ after birth values were similar to those born vaginally. There was no difference in leptin mRNA between cesarean section versus vaginally delivered lambs at $6 \mathrm{~h}$ of age (cesarean section, $4.5 \pm 4 \% 18 \mathrm{~s}$ rRNA; vaginally delivered, $9 \pm 3 \% 18 \mathrm{~S}$ rRNA). In vaginally delivered lambs, but not those born by cesarean section, there was a significant positive correlation between body weight and plasma leptin $\left(r^{2}\right.$ $=0.22 ; y=1.26 x+3.45 ; n=20 ; p<0.05)$. Although there was no effect of lamb sex on plasma leptin or perirenal adipose tissue weight, a significant positive correlation between plasma leptin and adipose tissue weight per kilogram of body weight was observed in male, but not female, lambs born by cesarean section $\left(r^{2}=0.85 ; y=3.36 x+0.66 ; n=7 ; p<0.001\right)$.

Study 2: Postnatal ontogeny. Plasma concentrations of leptin increased during the first $7 \mathrm{~d}$ after birth and then decreased in lambs to 1 month of age (Fig. 4A). This was associated with an increase in leptin mRNA abundance during the first $7 \mathrm{~d}$ of postnatal life (Fig. 5). Leptin mRNA abundance then declined, and there was no difference in either plasma leptin (e.g. $0 \mathrm{~d}: 0.9$ $\pm 0.2 \mathrm{ng} / \mathrm{mL} ; 30 \mathrm{~d}: 2.4 \pm 0.8 \mathrm{ng} / \mathrm{mL} ; n=6$ ) or mRNA abundance between newborn and 30-d-old lambs despite perirenal adipose tissue weight increasing $(0 \mathrm{~d}: 17.5 \pm 1.3 \mathrm{~g} ; 30 \mathrm{~d}$ : $152.7 \pm 7.1 \mathrm{~g} ; p<0.001)$.

Between birth and $7 \mathrm{~d}$ of age, i.e. during the period in which plasma leptin increased, plasma leptin was positively correlated to whole body and perirenal adipose tissue weights and mRNA abundance, which was also positively correlated with whole body and perirenal adipose tissue weights (Fig. 6). During the 7-d period in which both plasma leptin and its mRNA increased, plasma cortisol declined (Fig. 4B). Leptin mRNA abundance was negatively correlated with plasma cortisol during this period $\left(r^{2}=0.72 ; y=-0.304 x+77 ; n=9\right.$; $p=0.002)$. Similar relationships were not observed at subsequent ages, i.e. from 7 to $30 \mathrm{~d}$ after birth when plasma leptin decreased and plasma cortisol remained unchanged.

\section{DISCUSSION}

The major finding in the present study is that the decline in plasma leptin within $6 \mathrm{~h}$ after birth is coincident with the loss of mRNA for leptin in adipose tissue and that these changes are dependent on delivery temperature. These findings indicate that a decrease in leptin secretory capacity within adipose tissue as well as removal of the placenta as a fetal source of leptin may both contribute to a decrease in plasma leptin after birth (7). In lambs delivered by cesarean section delivery into a cool ambient temperature, leptin mRNA abundance was at the lower limits of detection (20). Low leptin mRNA might benefit the neonate by reducing leptin secretion into the circulation, thereby maximizing the appetite of the animal at a time when metabolic demands are high (9). These results are in accord with those from newborn rats in which food withdrawal and concomitant negative energy balance results in a reduction in leptin mRNA (21). The decline in plasma leptin after birth 
A
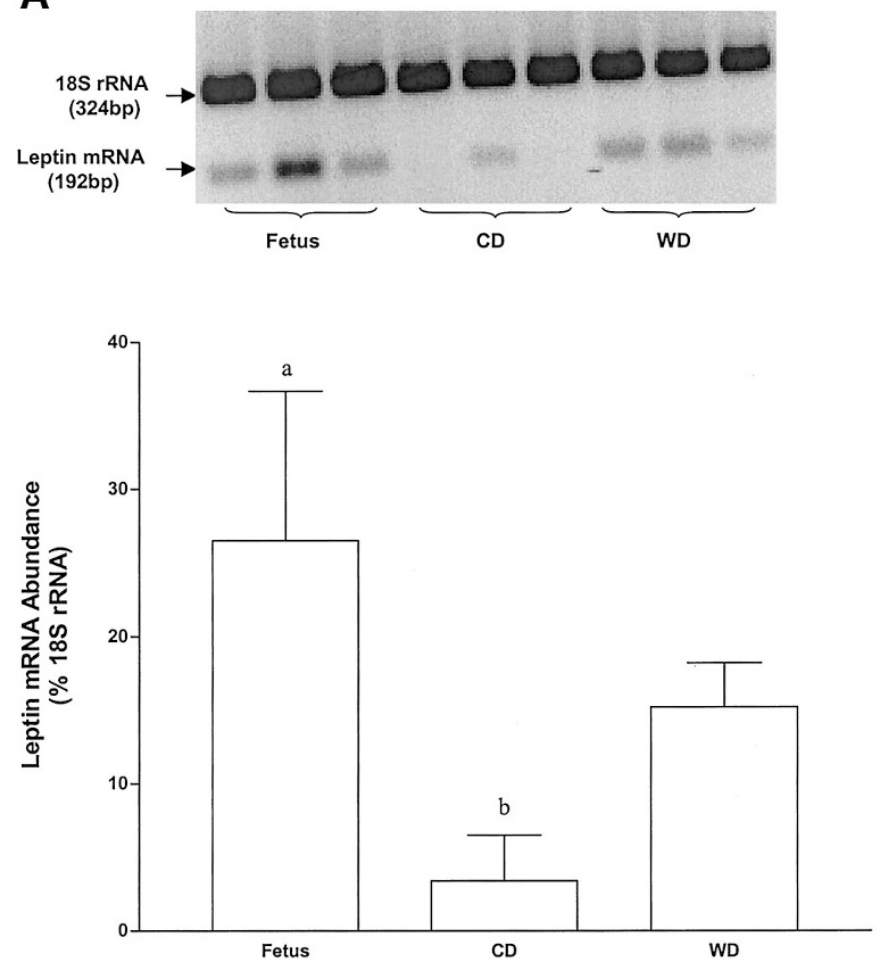

B

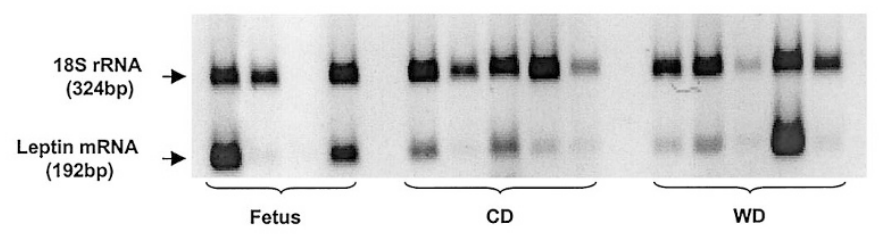

Figure 2. Influence of ambient temperature on leptin mRNA abundance in perirenal adipose tissue of neonatal lambs as measured using RT-PCR expression analysis. Examples of leptin expression in $(A)$ near-term fetus, and 6-h-old lambs delivered by cesarean section into a cool $\left(15^{\circ} \mathrm{C} ; C D\right)$ or warm $\left(30^{\circ} \mathrm{C}\right.$; $\left.W D\right)$ ambient temperature and $(B)$ 140-d fetus and 6-h-old lambs delivered by cesarean section into a cool $\left(15^{\circ} \mathrm{C} ; C D\right)$ or warm $\left(30^{\circ} \mathrm{C}\right.$; $\left.W D\right)$ ambient temperature after $2 \mathrm{~d}$ of maternal dexamethasone treatment. Bar graphs illustrate means + SEM ( $n=3-4$ per group), with significant differences between groups indicated by different letters: a $v s$ b, $p<0.05$.

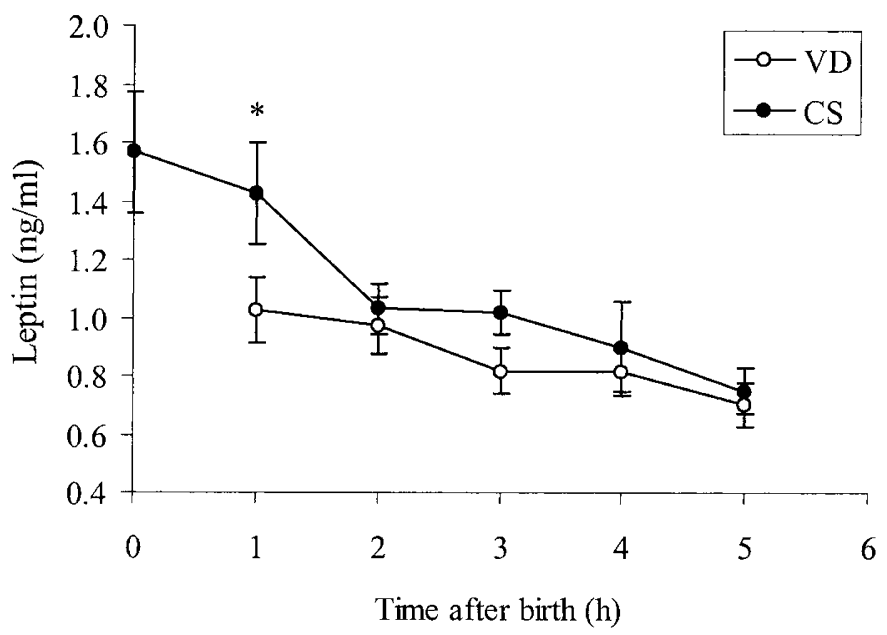

Figure 3. Effect of route of delivery on plasma concentrations of leptin. Closed symbols are cesarean section-delivered lambs $(C S)$, and open symbols are lambs born vaginally $(V D)$. Values are means \pm SEM $(n=10-20$ per group) with significant differences between groups indicated by $* p<0.05$.

is in accord with findings in infants $(6,7)$, although as discussed below, fetal lambs have much lower leptin concentrations than infants.

The difference in leptin mRNA with respect to delivery temperature was not associated with immediate changes in plasma leptin, which normally determines appetite, and may be determined by rate of clearance from the circulation rather than production rate. In this respect, there was a delay in the decline in plasma leptin after cesarean section, compared with vaginal birth, which could be a result of the initial suppressed metabolic rate in cesarean section-delivered lambs as colonic temperature declines (9), thereby reducing leptin clearance. Once the lamb has effectively adapted to the extrauterine environment, plasma leptin and mRNA abundance are positively correlated during the first week of postnatal life. This adaptation may be partly mediated by the decrease in plasma cortisol, which similarly occurred during the first $7 \mathrm{~d}$ of neonatal life. Plasma cortisol was negatively correlated with leptin mRNA abundance, suggesting that cortisol does not enhance leptin secretion in vivo after birth (22), although this remains to be studied in detail.

Dexamethasone and leptin. The effect of delivery temperature on leptin mRNA was not apparent in lambs born to ewes that had been administered with dexamethasone for $2 \mathrm{~d}$ before delivery. Dexamethasone promotes maturation of brown adipose tissue to the extent that lambs born 1 week prematurely are better able to effectively thermoregulate and have more UCP1 (14). Clinical studies have demonstrated plasma leptin to be increased 3-fold after maternal steroid treatment (13), although whether this was because of a change in leptin secretion by the placenta or fetal adipose tissue has not been established. We have shown that dexamethasone had no effect on leptin mRNA abundance in lambs. It should be noted, however, that plasma leptin concentrations in cord blood of lambs are appreciably lower than reported in infant cord blood. The lower levels of leptin in term-lambs compared with infants 

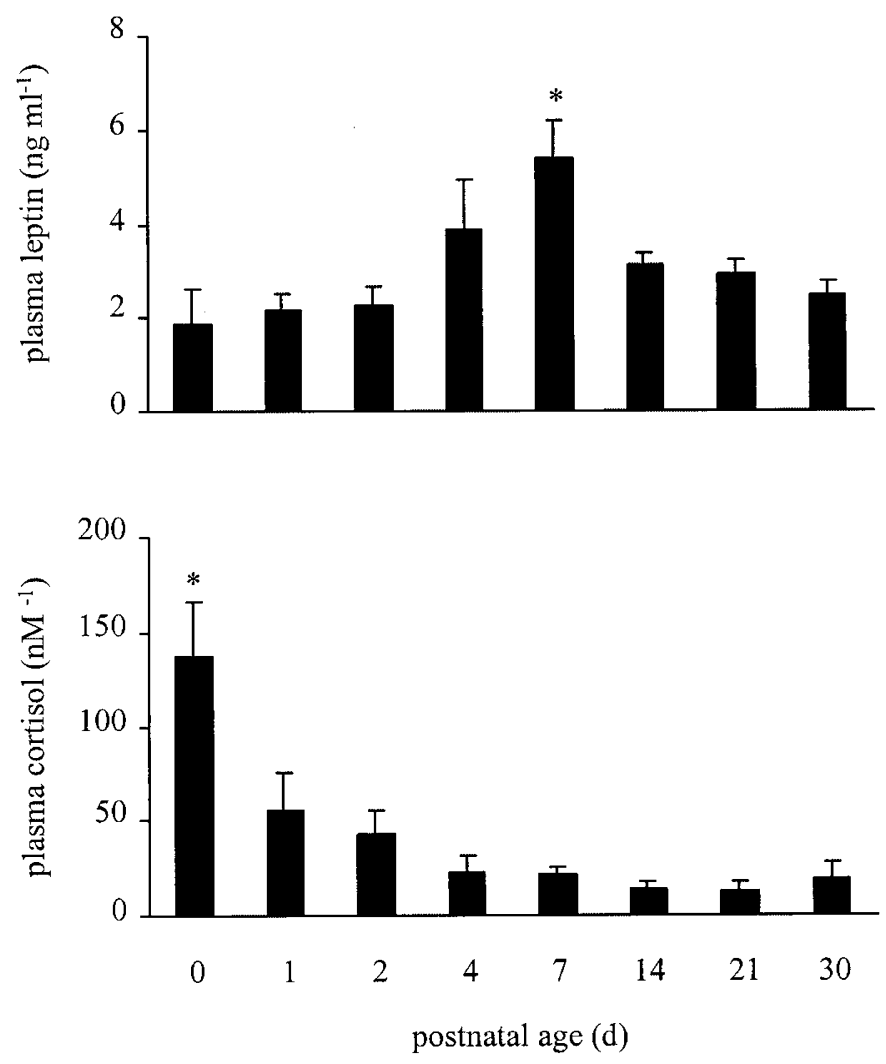

Figure 4. Postnatal ontogeny of plasma leptin $(A)$ and cortisol $(B)$ concentrations in lambs reared with their ewes. Values are means + SEM $(n=5-6$ per time), and significant differences with postnatal age are indicated by $* p<$ 0.05 .

[i.e. $20 \mathrm{ng} / \mathrm{mL}$ (16) compared with $1-1.5 \mathrm{ng} / \mathrm{mL}$ ] are likely to reflect smaller amounts of adipose tissue in lambs, primarily because of the lack of s.c. adipose tissue.

In adults, both peripheral and central adipose tissue stores are equally sensitive to the positive effect of dexamethasone on leptin mRNA expression in vitro (23). The lack of a reduction in leptin mRNA in cool-delivered dexamethasone-treated lambs may be indicative of increased mRNA stability (24) and override any peripheral signals, such as increased catecholamines, which would normally inhibit leptin secretion (25). These temperature-related differences in leptin mRNA abundance could have contributed to the improved thermoregulation after cesarean section birth into a cool ambient temperature (14). To this extent, an acute increase in plasma leptin improves the ability of neonates to maintain colonic temperature (26).

Leptin and postnatal development. Another major finding of the present study is that we have shown a concomitant rise in plasma leptin and leptin mRNA in parallel with increased perirenal adipose tissue deposition during the first $7 \mathrm{~d}$ of neonatal life. The postnatal rise in leptin is in accordance with findings in rat pups in which circulating concentrations of leptin peak at $10 \mathrm{~d}$ after birth (27). In lambs, plasma leptin and mRNA in adipose tissue were both positively correlated with whole body and perirenal adipose tissue weights. After $7 \mathrm{~d}$ of age, although adipose tissue growth continues, there is a decline in plasma leptin and mRNA but no correlation between
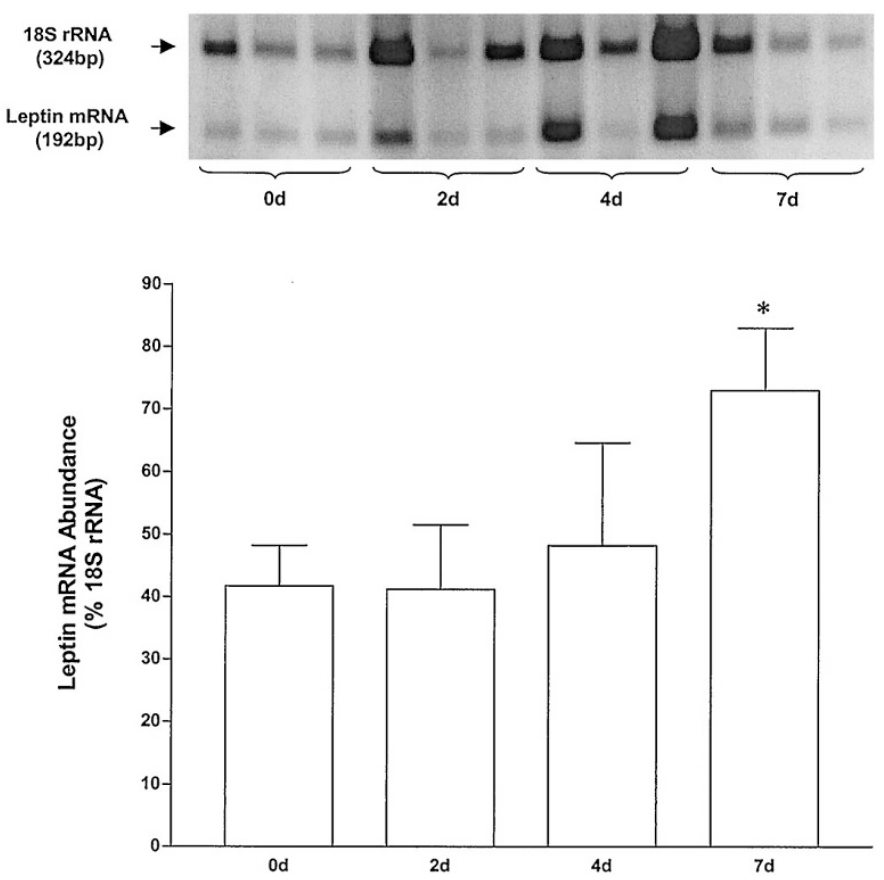

Figure 5. Postnatal ontogeny of leptin mRNA expression as measured using RT-PCR expression analysis. Bar graphs illustrate means + SEM $(n=3$ per group), and significant differences with postnatal age are indicated by $* p<$ 0.05 .

these variables. The rise in leptin during the first week of neonatal life occurs in parallel with an increase in cell volume (28) but no change in adipocyte number (29). It also coincides with the period in which plasma cortisol declines and thyroid hormone concentrations increase (30); as the lamb improves its thermal efficiency, colonic temperature increases from $39^{\circ}$ to $40^{\circ} \mathrm{C}$ (31) and UCP1 disappears (10). These adaptations, together with the positive effect leptin can have on thermoregulation (26), will all act to promote the partition of endogenous energy toward tissue growth rather than heat production.

It is hypothesized that leptin has a direct or permissive role in growth regulation only during late gestation (5) and the immediate neonatal period. The potential influence of leptin on growth may be limited to specific periods when nutrient supply is limited, namely, when the fetus is dependent on the placenta, and the lamb on initiation of lactation, to meet all their nutrient requirements. Indeed, it is has been proposed that one signal for the onset of parturition is failure to fully meet the energy requirements of the fetus $(32,33)$. It is only once lactation is fully established, and food intake is no longer limited by substrate availability, that leptin production by adipose tissue declines, ensuring maximal dietary intake.

In conclusion, leptin mRNA abundance can be determined by delivery temperature and is developmentally regulated during the first week of neonatal life. During these first few hours after birth, modest changes in ambient temperature or maternal dexamethasone administration can alter leptin mRNA abundance, which may contribute to altered adipose tissue function in postnatal life. 

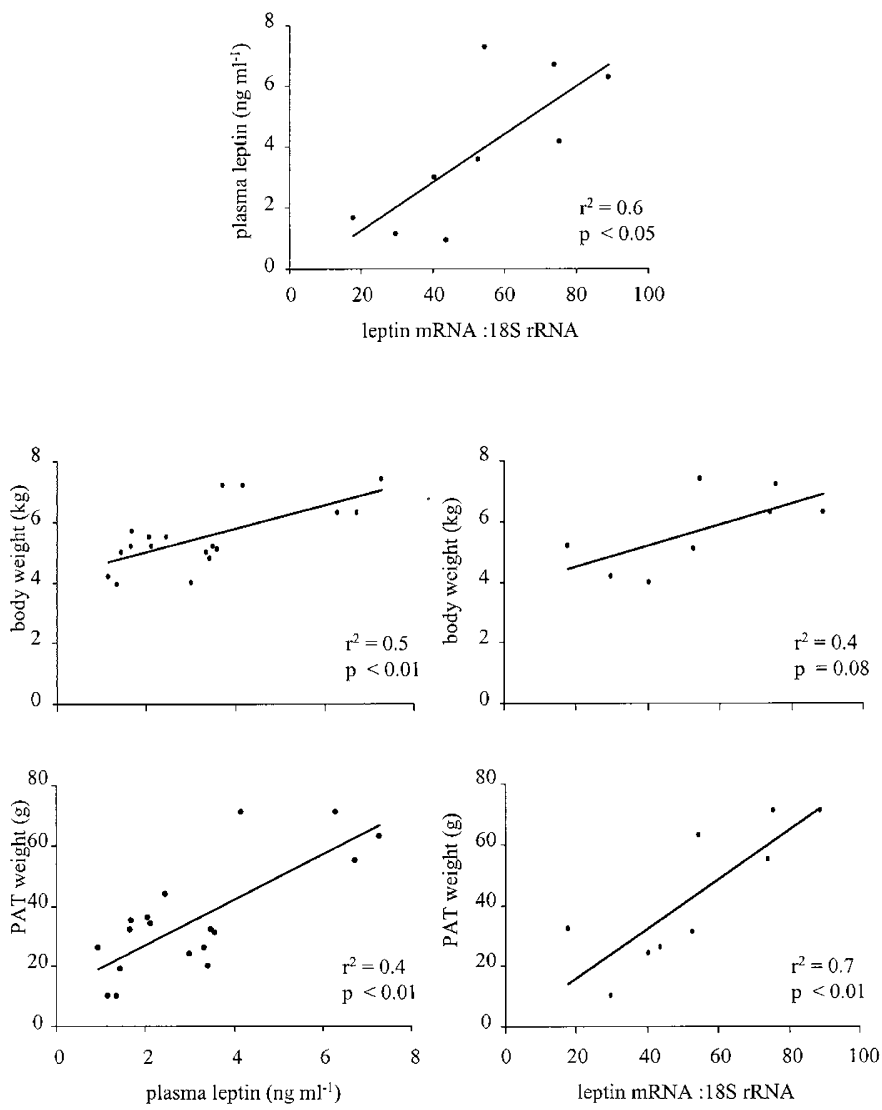

Figure 6. Positive relationships between plasma levels of leptin and leptin mRNA abundance in perirenal adipose tissue $(P A T)$ during the first week of neonatal life and whole body and adipose tissue weights.

\section{REFERENCES}

1. Zhang Y, Proenca R, Maffei M, Barone M, Leopold L, Friedman JM 1994 Positional cloning of the mouse obese gene and its human homologue. Nature 372:425-432

2. Ahima RS, Flier JS 2000 Leptin. Annu Rev Physiol 62:413-437

3. Friedman JM, Halaas JL 1998 Leptin and the regulation of body weight in mammals. Nature 395:763-770

4. Cetin I, Morpurga PS, Radaelli T, Taricco E, Cortelazzi D, Bellotti M, Pardi G, Beck-Peccoz P 2000 Fetal plasma leptin concentrations: relationship with different intrauterine growth patterns from 19 weeks to term. Pediatr Res 48:646-651

5. Yuen BSJ, McMillen IC, Symonds ME, Owens JA 1999 Abundance of leptin messenger ribonucleic acid in fetal adipose tissue is related to fetal body weight. J Endocrinol 163:R1-R4

6. Hytinantti T, Koistinen HA 1999 Changes in leptin concentration during the early postnatal period: adjustment to extrauterine life? Pediatr Res 45:197-201

7. Masuzaki H, Ogawa Y, Sagawa N, Hosoda K, Matsu-moto T, Mise H, Nishimura H, Yoshimasa Y, Tanaka I, Mori T, Nakao K 1997 Non-adipose tissue production of leptin: leptin as a novel placenta-derived hormone in humans. Nat Med 3:1029-1033

8. Clarke L, Bryant MJ, Lomax MA, Symonds ME 1997 Maternal manipulation of brown adipose tissue and liver development in the ovine fetus during late gestation. Br J Nutr 77:871-883
9. Clarke L, Heasman L, Firth K, Symonds ME 1997 Influence of route of delivery and ambient temperature on thermoregulation in newborn lambs. Am J Physiol 272:R1931-R1939

10. Clarke L, Buss DS, Juniper DS, Lomax MA, Symonds ME 1997 Adipose tissue development during early postnatal life in ewe-reared lambs. Exp Physiol 82:10151017

11. Casteilla L, Champigny O, Bouillaud F, Robelin J, Ricquier D 1989 Sequential changes in the expression of mitochondrial protein mRNA during the development of brown adipose tissue in bovine and ovine species. Biochem J 257:665-671

12. Fowden AL, Li J, Forhead AJ 1998 Glucocorticoids and the preparation for life after birth: are there long-term consequences of the life insurance? Proc Nutr Soc 57:113122

13. Shekhawat PS, Garland JS, Shivpuri C, Mick G, Sasidharan P, Pelz CJ, McCormick KL 1998 Neonatal cord blood leptin: its relationship to birth weight, body mass index, maternal diabetes, and steroids. Pediatr Res 43:338-413

14. Clarke L, Heasman L, Symonds ME 1998 Influence of maternal dexamethasone administration on thermoregulation in lambs delivered by caesarean section. J Endocrinol 156:307-314

15. Lepercq J, Caucaz M, Lahlou N, Timsit J, Girard J, Auwerx J, de Mouzan SH 1998 Overexpression of placental leptin in diabetic pregnancy. Diabetes 47:847-850

16. Matsuda J, Yokoto I, Iida M, Murakami T, Yamada M, Saijo T, Naito E, Ito M, Shima K, Kuroda Y 1999 Dynamic changes in serum leptin concentrations during the fetal and neonatal periods. Pediatr Res 45:71-75

17. Yuan C, Attele AS, Zhang L, Lynch JP, Xie J, Shi ZQ 2000 Leptin reduces body weight gain in neonatal rats. Pediatr Res 48:380-383

18. Clarke L, Bird JA, Lomax MA, Symonds ME 1996 Effect of $\beta_{3}$-adrenergic agonist (Zeneca D7114) on thermoregulation in near-term lambs delivered by cesarean section. Pediatr Res 40:330-336

19. Delavaud C, Bocquier F, Chilliard Y, Keisler DH, Gertler A, Kann G 2000 Effect of sheep nutritional status and body fatness on plasma leptin concentration assessed by a specific RIA. J Endocrinol 165:519-526

20. Thomas L, Wallace JM, Aitken RP, Mercer JG, Trayhurn P, Hoggard N 2001 Circulating leptin during ovine pregnancy in relation to maternal nutrition, body composition and pregnancy outcome. J Endocrinol 169:465-476

21. Dessolin S, Schalling M, Champigny O, Lonnqvist F, Ailhaud G, Dani C, Ricquier D 1997 Leptin gene is expressed in rat brown adipose tissue at birth. FASEB J 11:382-387

22. Arvaniti K, Ricquier D, Champigny O, Richard D 1998 Leptin and corticosterone have opposite effects on food intake and the expression of UCP1 mRNA in brown adipose tissue of $l e p^{o b} / l e p^{o b}$ mice. Endocrinology 139:4000-4003

23. Russel CD, Petersen RN, Rao SP, Ricci MR, Prasad A, Zhang Y, Brolin RE, Fried SK 1998 Leptin expression in adipose tissue from obese humans: depot specific regulation by insulin and dexamethasone. Am J Physiol 275:E507-E515

24. Beran RK, Simons RW 2001 Cold-temperature induction of Escherichia coli polynucleotide phosphorylase occurs by reversal of its autoregulation. Mol Microbiol 39:112-125

25. Trayhurn P, Duncan JS, Hoggrad N, Rayner DV 1998 Regulation of leptin production: a dominant role for the sympathetic nervous system? Proc Nutr Soc 57:413-419

26. Mostyn A, Keisler DH, Webb R, Stephenson T, Symonds ME 2001 The role of leptin in the transition from fetus to neonate. Proc Nutr Soc 60:187-194

27. Rayner DV, Dalgliesh GD, Duncan JS, Hardie LJ, Hoggard N, Trayhurn P 1997 Postnatal development of the $o b$ gene system: elevated leptin levels in suckling fa/fa rats. Am J Physiol 273:R446-R450

28. Vernon RG 1977 Development of perirenal adipose tissue in the neonatal lamb: effects of dietary safflower oil. Biol Neonate 32:15-23

29. Darby CJ, Clarke L, Lomax MA, Symonds ME 1996 Brown adipose tissue and liver development during early postnatal life in hand-reared and ewe-reared lambs. Reprod Fertil Dev 8:137-145

30. Symonds ME, Andrews DC, Johnson PJ 1989 The control of thermoregulation in the developing lamb during slow wave sleep. J Dev Physiol 11:289-298

31. Symonds ME, Bryant MJ, Clarke L, Darby CJ, Lomax MA 1992 Effect of maternal cold exposure on brown adipose tissue and thermogenesis in the neonatal lamb. J Physiol, (Lond) 455:487-502

32. McMillen IC, Phillips ID, Ross JT, Robinson JS, Owens JA 1995 Chronic stress - the key to parturition? Reprod Fertil Dev 7:197-206

33. Warnes K, Morris MJ, Symonds ME, Phillips ID, Owens JA, McMillen IC 1998 Effects of gestation, cortisol and maternal undernutrition on hypothalamic neuropeptide Y mRNA levels in the sheep fetus. J Neuroendocrinol 10:51-57 